\begin{tabular}{|c|c|c|c|}
\hline \multirow{2}{*}{$\begin{array}{r}\text { Case Reports in } \\
\text { Gastroenterology }\end{array}$} & \multicolumn{2}{|c|}{ Case Rep Gastroenterol 2015;9:7-14 } & \multirow[b]{2}{*}{$\begin{array}{l}\text { Karger } \\
\text { Open'access }\end{array}$} \\
\hline & $\begin{array}{l}\text { DOI: 10.1159/000373883 } \\
\text { Publisned online: January 15, } 2015\end{array}$ & $\begin{array}{l}\text { (C) } 2015 \text { S. Karger AG, Basel } \\
1662-0631 / 15 / 0091-0007 \$ 39.50 / 0 \\
\text { www.karger.com/crg }\end{array}$ & \\
\hline & \multicolumn{2}{|c|}{$\begin{array}{l}\text { This is an Open Access article licensed under the terms of the Creative Commons } \\
\text { Attribution-NonCommercial } 3.0 \text { Unported license (CC BY-NC) (www.karger.com/OA } \\
\text { license), applicable to the online version of the article only. Distribution permitted for non } \\
\text { commercial purposes only. }\end{array}$} & \\
\hline
\end{tabular}

\title{
Dysmetabolic Hyperferritinemia: All Iron Overload Is Not Hemochromatosis
}

\author{
Jasbir Makker ${ }^{a, b} \quad$ Ahmad Hanif ${ }^{b} \quad$ Bharat Bajantri $^{b} \quad$ Sridhar Chilimuri $^{a, b}$ \\ ${ }^{a}$ Division of Gastroenterology and ${ }^{b}$ Department of Medicine, Bronx Lebanon Hospital \\ Center, Albert Einstein College of Medicine of Yeshiva University, Bronx, N.Y., USA
}

\section{Key Words}

Hyperferritinemia · Transferrin saturation · Dysmetabolic hyperferritinemia ·

Hemochromatosis · Iron overload

\begin{abstract}
Disturbances in iron metabolism can be genetic or acquired and accordingly manifest as primary or secondary iron overload state. Organ damage may result from iron overload and manifest clinically as cirrhosis, diabetes mellitus, arthritis, endocrine abnormalities and cardiomyopathy. Hemochromatosis inherited as an autosomal recessive disorder is the most common genetic iron overload disorder. Expert societies recommend screening of asymptomatic and symptomatic individuals with hemochromatosis by obtaining transferrin saturation (calculated as serum iron/total iron binding capacity $\times 100$ ). Further testing for the hemochromatosis gene is recommended if transferrin saturation is $>45 \%$ with or without hyperferritinemia. However, management of individuals with low or normal transferrin saturation is not clear. In patients with features of iron overload and high serum ferritin levels, low or normal transferrin saturation should alert the physician to other - primary as well as secondary causes of iron overload besides hemochromatosis. We present here a possible approach to patients with hyperferritinemia but normal transferrin saturation.

(C) 2015 S. Karger AG, Basel
\end{abstract}

\section{Introduction}

The normal total body iron content of 3-4 $\mathrm{g}$ is the result of a tight balance between iron absorbed from the gastrointestinal tract and iron lost in stool, sweat and via shed skin cells. If the iron supply or gastrointestinal tract absorption of dietary iron exceeds the amount needed, there is no mechanism to eliminate the excessive iron. This state of presence of iron

KARGER125/s $\quad \begin{aligned} & \text { Jasbir Makker } \\ & \text { 8 Park Ave Unit } 4 \\ & \text { Goldens Bridge, NY } 10526 \text { (USA) } \\ & \text { E-Mail makkerjs@gmail.com }\end{aligned}$


Makker et al.: Dysmetabolic Hyperferritinemia: All Iron Overload Is Not Hemochromatosis

in excess of what is needed is called iron overload. Iron overload diseases are frequently associated with hereditary defects or secondary disturbances of iron metabolism that result from excessive blood transfusions, iron supplementation or iron injections. Hereditary hemochromatosis, which is characterized by a genetic predisposition to absorb excess iron from the diet, is the most frequent form of genetic iron overload.

Iron overload, irrespective of the underlying etiology, has varying manifestations, depending on the organs affected by the excessive iron deposit. It may present as fatigue, skin color changes, abdominal pain, joint pain, irregular menstruation, infertility, impotence, irregular heart rhythm, heart failure, new-onset diabetes or difficulty controlling established diabetes and elevation in liver enzymes. Hemochromatosis, the most common genetic iron overload disorder, may also lead to the development of life-threatening complications like cirrhosis and hepatocellular carcinoma [1].

Manifestations of iron overload in hemochromatosis are related to mutations of the HFE gene, but not all patients with an inherited hemochromatosis-like phenotype carry pathogenic mutations in the HFE gene [2]. Several other genetic mutations involving the hemojuvelin, the hepcidin, the transferrin receptor 2 and the ferroportin gene have been discovered and known to cause manifestations similar to classic hereditary hemochromatosis. The hemojuvelin and hepcidin genes are implicated in causing juvenile hemochromatosis, transferrin receptor 2 gene mutation causes type 3 hemochromatosis, and ferroportin gene mutation leads to ferroportin disease. These diseases were traditionally classified under non-HFE hemochromatosis, but recently the identification of new iron genes has made it possible to distinctly identify these disorders.

\section{Case Presentation}

A 55-year-old male presented with worsening shortness of breath and palpitations. He had been well until 1 week prior to presentation, when he started feeling short of breath initially on exertion, but later at rest. He also reported orthopnea. He had intermittent cough productive of white sputum and wheezing. He was anxious and tremulous. Since the onset of symptoms his exercise tolerance had declined from a baseline of more than ten blocks to two blocks. He reported no fever, chest pain, dizziness, syncope, rash or weight loss.

His medical history included hypertension, diabetes mellitus and hyperlipidemia. Medications at the time of presentation included aspirin $81 \mathrm{mg}$ daily, hydrochlorothiazide $12.5 \mathrm{mg}$ daily, diltiazem $30 \mathrm{mg}$ three times a day, losartan $25 \mathrm{mg}$ daily as well as fenofibrate and subcutaneous insulin (70/30) 40 units twice a day. He had undergone appendectomy 10 years before for acute appendicitis. He was allergic to seafood and ACE inhibitors. He reported active tobacco use with a five pack year history of smoking, drank three beers daily and had occasionally snorted cocaine, but stopped 2 years earlier. He had been born in US, had studied until 11th grade and had worked in a food store, but was currently unemployed. He was living in an apartment with his wife and was sexually active in a monogamous relationship. His mother and sister have diabetes mellitus and his father had died of an unknown cancer.

On examination, he was afebrile. His pulse rate was 100 beats per minute, blood pressure $142 / 84 \mathrm{~mm} \mathrm{Hg}$, respiratory rate 18 breaths per minute with oxygen saturation $94 \%$ on room air that improved to $100 \%$ on 2 liters of oxygen through a nasal cannula, and his body mass index was 28.8. He appeared comfortable. Cardiac examination revealed normal heart sounds and no jugular venous distention. There were bibasilar rales on auscultation of the lungs and no wheezing. The abdomen was non-distended, soft and non-tender; the liver 
Makker et al.: Dysmetabolic Hyperferritinemia: All Iron Overload Is Not Hemochromatosis

was palpable $5 \mathrm{~cm}$ below the right costal margin and bowel sounds were normal. He was alert and fully oriented, with motor strength and sensation normal in all extremities. Extremity examination was unremarkable, without any edema.

Hematocrit was $41.2 \%$, white blood cell count $6.4 \times 10^{9} / \mathrm{l}$ and platelet count $245 \times 10^{9} / \mathrm{l}$. The basic metabolic panel including serum sodium, serum potassium, blood urea nitrogen and serum creatinine was normal. The results of liver function tests, iron studies and tests to evaluate other etiologies of elevated transaminases are given in table 1 . The blood level of proBNP was elevated to $1,002 \mathrm{pg} / \mathrm{ml}$ and hemoglobin A1C was $7.8 \%$. Serologic human immunodeficiency virus testing and urine toxicology screen were negative. Electrocardiogram revealed sinus tachycardia, left atrial enlargement and QT interval prolongation. Chest X-ray showed pulmonary vascular congestion but no infiltrates. Echocardiogram showed severely reduced ejection fraction of $32 \%$ with global hypokinesis and eccentric left ventricular hypertrophy. Ultrasound of the abdomen revealed a large heterogeneous liver measuring $18 \mathrm{~cm}$ in length.

The patient was admitted to hospital with an initial impression of systolic congestive heart failure. He was treated with intravenous furosemide for diuresis with subsequent rapid symptomatic improvement. High levels of serum ferritin in conjunction with the clinical findings of heart failure, hepatomegaly and diabetes mellitus suggested an iron overload state. We expected the transferrin saturation to be $>45 \%$, as seen in hereditary hemochromatosis, the most commonly identified genetic iron overload disorder. However, the calculated transferrin saturation was only $28 \%$. DNA mutation analysis showed that the patient was heterozygous for $\mathrm{C} 282 \mathrm{Y}$ mutation and negative for H63D mutation.

\section{Differential Diagnosis}

In a 55-year-old man with features of iron overload - elevated ferritin, diabetes mellitus, enlarged liver, elevated liver enzymes and heart failure - diseases under the following two categories [3] need consideration:

\section{Genetic Iron Overload}

(1) Type 1 hemochromatosis - HFE hemochromatosis. (2) Type 2 hemochromatosis juvenile hemochromatosis: (a) type $2 \mathrm{~A}$ - mutation in hemojuvelin gene; (b) type $2 \mathrm{~B}$ - mutation in hepcidin gene. (3) Type 3 hemochromatosis - transferrin receptor 2 hemochromatosis. (4) Type 4 hemochromatosis - ferroportin disease: (a) type 4A - with low transferrin saturation; (b) type 4B - with high transferrin saturation. (5) A(hypo)transferrinemia. (6) Aceruloplasminemia.

\section{Acquired Iron Overload}

(1) Iatrogenic: (a) multiple blood transfusions; (b) parenteral iron therapy; (c) oral iron therapy. (2) Chronic liver disease: (a) alcoholic liver disease; (b) hepatitis B and C; (c) porphyria cutanea tarda. (3) Anemias: (a) thalassemia major; (b) chronic hemolytic anemia; (c) pyruvate kinase deficiency. (4) Others: (a) dysmetabolic hyperferritinemia.

\section{Discussion}

Iron overload can manifest as fatigue, joint pain, liver disease, heart disease, hypogonadism, diabetes mellitus and skin pigmentation (bronze skin). Features of iron overload 
Makker et al.: Dysmetabolic Hyperferritinemia: All Iron Overload Is Not Hemochromatosis

with an abnormal gene point towards a differential diagnosis that includes hemochromatosis type 1 (HFE), hemochromatosis type 2 , hemochromatosis type 3 , hemochromatosis type 4, atransferrinemia and aceruloplasminemia. HFE hemochromatosis is the most common form of inherited iron overload among these disorders. It is an autosomal recessive disorder due to two mutant alleles, usually C282Y, of the HFE gene and is characterized by tissue iron overload with potential for organ disease $[2,4]$. In a patient with signs of tissue iron overload with increased plasma iron content, as evidenced by hyperferritinemia and increased transferrin saturation, genetic testing for C282Y mutation of the HFE gene should be performed for diagnosis of HFE hemochromatosis. Approximately 85-90\% of patients with inherited forms of iron overload are homozygous for C282Y mutation in HFE. A very small proportion of patients are compound heterozygotes, and either have one allele with C282Y mutation and the other allele with H63D mutation (C282Y/H63D), or one allele with C282Y mutation and the other allele with S65C mutation (C282Y/S65C) [3]. The remaining $10-15 \%$ of patients with inherited forms of iron overload without pathogenic mutations in the HFE gene come under the definition of non-HFE hemochromatosis [5].

The second most common form of inherited iron metabolism disorder is ferroportin disease. Ferroportin disease was first described in 1999 as an autosomal dominant disorder with similar features as those of HFE hemochromatosis [6]. Clinically, the disease is usually limited to liver disease and mild anemia, however the full spectrum of clinical symptoms typical of hemochromatosis is seen in some patients. It is caused by mutation in the SLC40A1 gene, which codes for ferroportin protein. A comparison between hereditary hemochromatosis and ferroportin disease [2] is shown in table 2.

Ferroportin protein is expressed in enterocytes, macrophages, Kupffer cells, placental cells and hepatocytes, where it plays the role of an iron exporter. Ferroportin protein helps in release of both dietary iron from enterocytes as well as iron released by damaged or senescent red blood cells into the circulation (fig. 1). Expression of ferroportin, a transmembrane receptor protein, is regulated by its ligand, hepcidin [7]. Hepcidin, a negative regulator of iron absorption, binds to ferroportin transmembrane protein during states of excess iron or inflammation. This binding leads to internalization of ferroportin followed by its lysosomal degradation. The amount of iron released into the circulation by enterocytes and macrophages is reduced as a result [8]. On the other hand, during states of iron deficiency, there is a decline in the expression of hepcidin, and hence excess iron is released into the circulation. The mutation of ferroportin protein as in the case of ferroportin disease makes it resistant to hepcidin, hence removing the negative regulation and leading to excess iron release into the circulation.

In our patient, normal transferrin saturation along with heterozygosity for C282Y mutation made the diagnosis of hemochromatosis unlikely. Absence of extrapyramidal signs, cerebellar ataxia and dementia ruled out aceruloplasminemia. A(hypo)transferrinemia is an extremely rare autosomal recessive disorder of iron overload characterized by severe microcytic anemia [9], which was not present in this patient. Ferroportin disease is less likely in the absence of any family history of hyperferritinemia. However, a sporadic case of ferroportin disease cannot be completely excluded. The possibility of ferroportin disease should only be entertained once the more common secondary causes of hyperferritinemia are excluded.

Secondary or acquired iron overload state, in the absence of an abnormal gene, suggests disorders such as chronic hemolytic anemias, dysmetabolic hyperferritinemia, chronic liver disease due to alcohol, hepatitis B or C, porphyria cutanea tarda and iatrogenic iron overload conditions. 
Makker et al.: Dysmetabolic Hyperferritinemia: All Iron Overload Is Not Hemochromatosis

In the absence of hepatitis $C$ antibody or hepatitis B surface antigen in our patient, viral hepatitis B or C was very unlikely to be the cause. Absence of any skin lesions and photosensitivity excluded porphyria cutanea tarda. Our patient did not report any history of iron therapy, excluding iatrogenic overload. In the presence of normal hemoglobin and hematocrit, chronic hemolytic anemia was also unlikely to be the cause. Alcoholic liver disease was also unlikely to be the cause, as it is associated with elevated transferrin saturation [10]. Chronic alcohol use leads to downregulation of hepcidin, which alters the iron hemostasis, causing iron excess [11].

Dysmetabolic hyperferritinemia, also known as insulin resistance associated with iron overload, is a much more common disorder than recognized clinically by physicians. It is characterized by the presence of elevated serum ferritin, but normal transferrin saturation in an individual with features of metabolic syndrome. In our overweight patient, who had other features of metabolic syndrome including diabetes mellitus, hypertension and hyperlipidemia, this diagnosis seems most likely, especially in the absence of genetic mutation for HFE hemochromatosis and exclusion of other secondary causes of iron overload (fig. 2).

\section{Conclusion}

In a patient with signs and symptoms of tissue iron overload and high serum ferritin levels, low or normal transferrin saturation should alert the physician to other - primary as well as secondary - causes of iron overload besides hemochromatosis. Other primary iron overload conditions with normal transferrin saturation include ferroportin disease type A and aceruloplasminemia. Secondary iron overload conditions with normal transferrin saturation include dysmetabolic hyperferritinemia. Dysmetabolic hyperferritinemia, being more prevalent especially in the presence of metabolic syndrome, should be considered as the most likely disorder in such scenarios of high ferritin with normal transferrin saturation.

\section{Disclosure Statement}

The authors have no conflicts of interest or funding sources to disclose.

\section{References}

1 Adams P, Brissot P, Powell LW: EASL International Consensus Conference on Haemochromatosis. J Hepatol 2000;33:485-504.

2 Pietrangelo A: The ferroportin disease. Blood Cells Mol Dis 2004;32:131-138.

-3 Bacon BR, Adams PC, Kowdley KV, Powell LW, Tavill AS: Diagnosis and management of hemochromatosis: 2011 practice guideline by the American Association for the Study of Liver Diseases. Hepatology 2011;54: 328-343.

4 Pietrangelo A: Non-HFE hemochromatosis. Hepatology 2004;39:21-29.

5 Pietrangelo A: Hemochromatosis 1998: is one gene enough? J Hepatol 1998;29:502-509.

-6 Pietrangelo A, Montosi G, Totaro A, Garuti C, Conte D, Cassanelli S, Fraquelli M, Sardini C, Vasta F, Gasparini P: Hereditary hemochromatosis in adults without pathogenic mutations in the hemochromatosis gene. N Engl J Med 1999;341:725-732.

-7 Zhang DL, Hughes RM, Ollivierre-Wilson H, Ghosh MC, Rouault TA: A ferroportin transcript that lacks an iron-responsive element enables duodenal and erythroid precursor cells to evade translational repression. Cell Metab 2009;9:461-473.

-8 Nemeth E, Tuttle MS, Powelson J, Vaughn MB, Donovan A, Ward DM, Ganz T, Kaplan J: Hepcidin regulates cellular iron efflux by binding to ferroportin and inducing its internalization. Science 2004;306:2090-2093. 
Makker et al.: Dysmetabolic Hyperferritinemia: All Iron Overload Is Not Hemochromatosis

9 Aslan D, Crain K, Beutler E: A new case of human atransferrinemia with a previously undescribed mutation in the transferrin gene. Acta Haematol 2007;118:244-247.

10 Ioannou GN, Dominitz JA, Weiss NS, Heagerty PJ, Kowdley KV: The effect of alcohol consumption on the prevalence of iron overload, iron deficiency, and iron deficiency anemia. Gastroenterology 2004;126: 1293-1301.

11 Bridle K, Cheung TK, Murphy T, Walters M, Anderson G, Crawford DG, Fletcher LM: Hepcidin is down-regulated in alcoholic liver injury: implications for the pathogenesis of alcoholic liver disease. Alcohol Clin Exp Res 2006;30:106-112.

Table 1. Laboratory tests at admission

Liver function tests

Total protein

Serum albumin

Alanine aminotransferase (ALT)

Aspartate aminotransferase (AST)

Alkaline phosphatase (ALP)

Total bilirubin

Direct bilirubin

Other related tests

Hepatitis C virus antibody

Hepatitis B surface antigen

Hepatitis B surface antibody

Hepatitis B core IgM antibody

Hepatitis B core IgG antibody

Hepatitis A IgG antibody

Anti-nuclear antibody (ANA)

Anti-mitochondrial antibody

Liver kidney microsomal antibody

Anti-smooth muscle antibody

\section{Iron studies}

Serum ferritin

Serum iron

Unsaturated iron binding capacity

Transferrin saturation
$8.2 \mathrm{~g} / \mathrm{dl}$

$4.1 \mathrm{~g} / \mathrm{dl}$

$69 \mathrm{U} / \mathrm{l}$

$100 \mathrm{U} / \mathrm{l}$

$265 \mathrm{U} / \mathrm{l}$

$1.2 \mathrm{mg} / \mathrm{dl}$

$0.5 \mathrm{mg} / \mathrm{dl}$

negative

negative

positive

negative

positive

negative

negative

negative

negative

negative

$2,210 \mathrm{ng} / \mathrm{ml}$

$84 \mu \mathrm{g} / \mathrm{dl}$

$216 \mu \mathrm{g} / \mathrm{dl}$

$28 \%$ 
Makker et al.: Dysmetabolic Hyperferritinemia: All Iron Overload Is Not Hemochromatosis

Table 2. Comparison between hereditary hemochromatosis and ferroportin disease

\begin{tabular}{lll}
\hline & Hereditary hemochromatosis & Ferroportin disease \\
\hline Gene affected & HFE & SLC40A1 \\
\hline Gene location & short arm of chromosome 6 & long arm of chromosome 2 \\
\hline Gene function & $\begin{array}{l}\text { control of iron absorption through } \\
\text { regulation of hepcidin }\end{array}$ & $\begin{array}{l}\text { iron export from enterocytes and } \\
\text { reticuloendothelial cells }\end{array}$ \\
\hline Inheritance & autosomal recessive & autosomal dominant \\
\hline Prevalence & 1 in 200-300 & 1 in 1,000,000 \\
\hline Penetrance & $<50 \%$ & full penetrance \\
\hline Age at onset & $\begin{array}{l}40-60 \text { years } \\
\text { Pathology }\end{array}$ & $\begin{array}{l}\text { biochemical abnormalities appear } \\
\text { in 1st decade }\end{array}$ \\
\hline Main clinical features & $\begin{array}{l}\text { liver cirrhosis, arthropathy, cardiac } \\
\text { disease, endocrinopathy }\end{array}$ & $\begin{array}{l}\text { affects Kupffer cells } \\
\text { liver disease, anemia }\end{array}$ \\
\hline Laboratory features & $\begin{array}{l}\text { elevated ferritin with elevated } \\
\text { transferrin saturation }\end{array}$ & $\begin{array}{l}\text { elevated ferritin with normal } \\
\text { transferrin saturation }\end{array}$ \\
\hline Response to phlebotomy & well tolerated & \begin{tabular}{l} 
not well tolerated \\
\hline
\end{tabular}
\end{tabular}
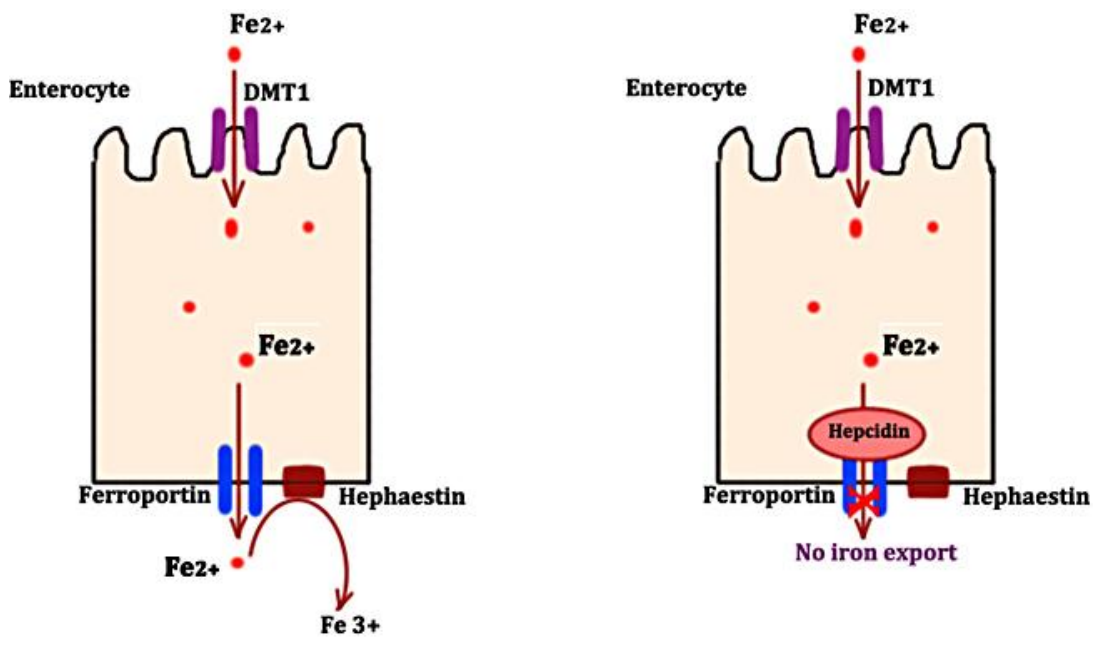

Fig. 1. Regulation of iron export from enterocytes by hepcidin and ferroportin interaction. DMT1: divalent metal transporter; $\mathrm{Fe}^{2+}$ : iron molecule in ferrous form; $\mathrm{Fe}^{3+}$ : iron molecule in ferric form. 


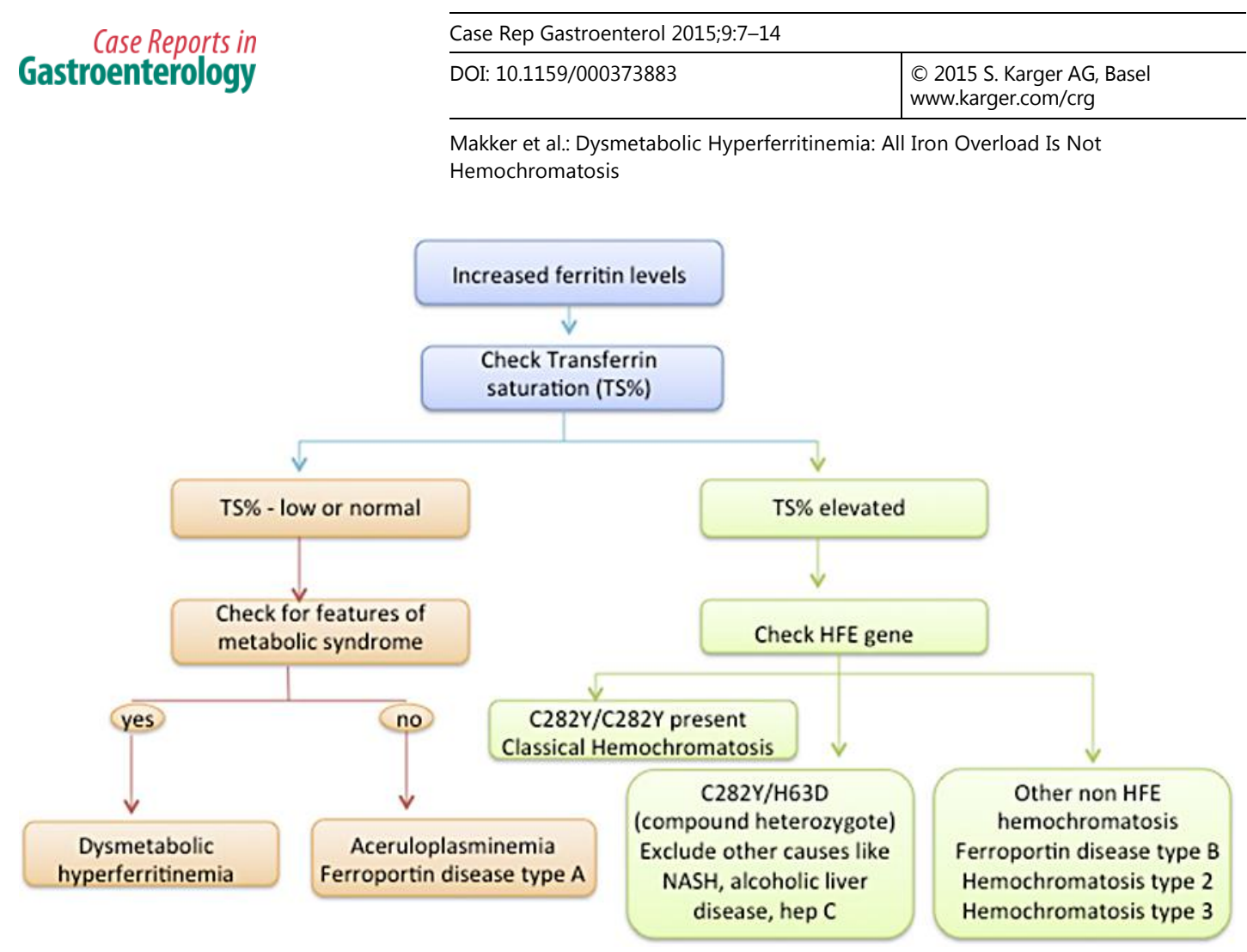

Fig. 2. Algorithm for patients with elevated ferritin and suspected iron overload. 